\title{
Removal of Chromium from Synthetic Tannery Effluent by Using Bioadsorbents
}

\author{
${ }^{1}$ A.Logeswari, ${ }^{2}$ S.Mano, ${ }^{3}$ A.Merly Xavier, ${ }^{4}$ Dr.M.Thirumarimurugan, \\ ${ }^{5}$ Dr.T.Kannadasan \\ ${ }^{1,2,3}$ student, ${ }^{4}$ Associate professor, ${ }^{5}$ Head of the Department,Department of chemical engineering, Coimbatore \\ Institute of Technology, Coimbatore-14
}

\begin{abstract}
Several low cost biomaterials such as rice husk,saw dust and eucalyptus bark (EB) were tested for removal of chromium. All the experiments were carried out in batch process with laboratory prepared samples. The adsorbent, which had highest chromium(VI) removal was EB. Influences of chromium concentration, contact time on removal of chromium from effluent was investigated. The adsorption data were fitted well by Langmuir isotherm. The maximum removal of $\mathrm{Cr}(\mathrm{VI})$ was observed at $\mathrm{pH}$ 2. Adsorption capacity was found to be $45 \mathrm{mg} / \mathrm{g}$ of adsorbent, at $\mathrm{Cr}(\mathrm{VI})$ concentration in the effluent being 200mg/l,250 mg/l. The results indicate that eucalyptus bark can be used for the removal of chromium.
\end{abstract}

\section{Introduction:}

The wastewater from industries varies so greatly in both flow and pollutional strength. [1].The presence of heavy metals in drinking water can be hazardous to consumers; these metals can damage nerves, liver and bones and block functional groups of vital enzymes [2].Process waste streams from tanneries may contain heavy metals at concentrations exceeding the local discharge limits..[3].These metals cannot be degraded or readily detoxified biologically and have tendency to accumulate in living material [4].Health and environmental issues derived from waste effluents are universally acknowledged problems. It is therefore necessary to find cheap and simple decontamination methods.[5]. $\mathrm{Cr}(\mathrm{VI})$ has been reported to be a primary contaminant to humans, animals, plants and microorganisms and it is known to be carcinogenic[6]. Chromium compounds, such as hexavalent chromium, are widely used in electroplating, stainless steel production, leather tanning, textile manufacturing, and in wood preservation [8]. .Chromium occurs in a number of oxidation states, but $\mathrm{Cr}(\mathrm{III})$ (trivalent chromium) and $\mathrm{Cr}(\mathrm{IV})$ (hexavalent chromium) are of main biological relevance. There is a great difference between $\mathrm{Cr}$ (III)and $\mathrm{Cr}(\mathrm{VI})$ with respect to toxicological and environmental properties, [9]. .Hexavalent chromium may exist in aquatic media as water soluble complex anions and may persist in water[10].Hexavalent chromium is a strong oxidizing agent and may react with organic matter or other reducing agents to form trivalent chromium. [11]. The maximum levels permitted in wastewater are $5 \mathrm{mg} / \mathrm{L}$ for trivalent chromium and $0.05 \mathrm{mg} / \mathrm{L}$ for hexavalent chromium. With this limit, it is essential for industries to treat their effluents to reduce the $\mathrm{Cr}$ to acceptable levels. Due to more stringent environmental regulations, most of the mineral processing plants, metal-finishing industries are facing nowadays the difficult problem of disposal of wastewater produced in huge quantities, laden with Cr. Because of these important aspects in the precipitation of heavy metals, there is no way to predict the best solution of a specific problem without undergoing a series of bench tests to evaluate the alternative available [14].The present study is aimed at selection of a low cost biosorbent, which can adsorb chromium from the wastewater. Detailed batch studies with the selected adsorbent, eucalyptus bark,rice husk,sawdust have been carried out in the present investigation. The contact time, adsorbent concentration were also investigated.

1.3 Stoppered bottles

II. Materials And Methods:

2.4 Glass beakers

3.Filter paper

4. $\mathrm{P}^{\mathrm{H}}$ meter

5.UV Spectrophotometer

\section{Preparation Of Eucalyptus Bark Adsorbent}

Eucalyptus bark (EB) was initially grounded and washed with deionized water. The adsorbents were dried at room temperature, $\left(32 \pm 1{ }^{\circ} \mathrm{C}\right)$ till a constant weight of the adsorbent was achieved. A uniform particle size of the adsorbent was maintained between 120 and $500 \mu \mathrm{m}$. To avoid, the release of color by bark into the aqueous solution during adsorption, it was treated with formaldehyde. For this $5 \mathrm{ml}$ of aqueous formaldehyde 
was added to $100 \mathrm{ml}$ of $0.1 \mathrm{ml} \mathrm{H}_{2} \mathrm{SO}_{4}$ and then $10 \mathrm{~g}$ of grounded and washed bark was added to this solution. The final mixture was stirred and heated at $50{ }^{\circ} \mathrm{C}$ for $24-48 \mathrm{~h}$ till the mixture became thick slurry.The slurry (treated bark) was washed with deionized water until the $\mathrm{p}^{\mathrm{H}}$ of the filtrate was more than 4.5.Finally the bark was air-dried and sieved. Particles in the range of $120-500 \mu \mathrm{m}$ size were collected as the final adsorbent.

\section{Preparation Of Rice Husk Adsorbent}

The rice husk was initially washed and allowed to dry. Then it was treated with formaldehyde. $(5 \mathrm{ml}$ aq. formaldehyde).The final mixture was stirred and heated at $50{ }^{\circ} \mathrm{C}$ for $24-48 \mathrm{~h}$ till the mixture became thick slurry.The slurry (treated sawdust) was washed with deionized water until the $\mathrm{p}^{\mathrm{H}}$ of the filtrate was more than 4.5.Finally the sawdust was air-dried and sieved. Particles in the range of $210-420 \mu \mathrm{m}$ size were collected as the final adsorbent.

\section{Preparation Of Saw Dust Adsorbent}

The neem sawdust was used in this experiment is collected. It is sieved for the size of $210-420 \mu \mathrm{m}$. It is then subjected to the pre-treatments without washing. Then it was treated with formaldehyde. $(5 \mathrm{ml}$ aqueous formaldehyde)The final mixture was stirred and heated at $50{ }^{\circ} \mathrm{C}$ for $24-48 \mathrm{~h}$ till the mixture became thick slurry.The slurry (treated sawdust) was washed with deionized water until the $\mathrm{p}^{\mathrm{H}}$ of the filtrate was more than 4.5.Finally the sawdust was air-dried and sieved. Particles in the range of $210-420 \mu \mathrm{m}$ size were collected as the final adsorbent.

\section{Experimental Procedure:}

Stock solution is prepared. $10 \mathrm{~g}$ of adsorbent was added to $250 \mathrm{ml}$ stoppered bottle containing $100 \mathrm{ml}$ of synthetic effluent. Bottles were subjected to mechanical shaking at $32^{\circ} \mathrm{C}$.Contents of bottles were removed and filtered through filter paper. The filtrate was analysed for $\mathrm{p}^{\mathrm{H}}$. final chromium concentration was analysed using UV Spectrophotometer( with reference wave length of $540 \mathrm{~nm}$ ).

\section{Results And Discussions:}

Performance Of Various Adsorbents For Cr Removal: The performances of these sorbents were evaluated for the percent removal of chromium. The maximum (87.4\%) removal of chromium was achieved with EB. The variation in the sorption capacity between the various adsorbents could be related to the nature and concentration of surface groups responsible for interaction with the metal ions. The selected adsorbents were cellulose based plant fibers having many hydroxyl groups that may bind the $\mathrm{Cr}(\mathrm{VI})$ ion. Formaldehyde pretreatment of eucalyptus bark led to crosslinking of compounds in the bark to form a phenol-formaldehyde copolymer that preserved high capacity of the support towards the adsorption of cations. This can be explained by the interactions in the solutions between the cations and the water extracted moieties, leading to complexities that precipitate on the support surface (Saliba et al., 2002).

\section{Results:}

\begin{tabular}{|c|c|c|c|c|c|c|}
\hline & \multicolumn{6}{|c|}{ result } \\
\hline & \multicolumn{2}{|c|}{$\begin{array}{l}\text { synthetic tannery effluent } \\
1 \text { (treated) }\end{array}$} & \multicolumn{2}{|c|}{$\begin{array}{l}\text { synthetic tannery effluent } \\
2 \text { (treated) }\end{array}$} & \multicolumn{2}{|c|}{$\begin{array}{l}\text { synthetic tannery effluent } \\
3 \text { (treated) }\end{array}$} \\
\hline \multirow[t]{2}{*}{ adsorbent } & \multicolumn{2}{|c|}{ eucalptus bark } & \multicolumn{2}{|c|}{ saw dust } & \multicolumn{2}{|c|}{ rice husk } \\
\hline & $\begin{array}{l}\text { Time } \\
(\mathrm{min})\end{array}$ & \%adsorption & $\begin{array}{l}\text { Time } \\
(\mathrm{min})\end{array}$ & \%adsorption & $\begin{array}{l}\text { Time } \\
(\mathrm{min})\end{array}$ & \%adsorption \\
\hline \multirow{4}{*}{$\begin{array}{l}\text { chromium(sample } \\
1-200 \mathrm{ppm} \text { ) }\end{array}$} & 50 & 82 & 50 & 70 & 50 & 63 \\
\hline & 100 & 85 & 100 & 75 & 100 & 68 \\
\hline & 150 & 88 & 150 & 78 & 150 & 73 \\
\hline & 200 & 92 & 200 & 81 & 200 & 74 \\
\hline \multirow{4}{*}{$\begin{array}{l}\text { chromium(sample } \\
2-250 \mathrm{ppm} \text { ) }\end{array}$} & 50 & 58 & 50 & 52 & 50 & 51 \\
\hline & 100 & 66 & 100 & 55 & 100 & 58 \\
\hline & 150 & 78 & 150 & 60 & 150 & 62 \\
\hline & 200 & 81 & 200 & 62 & 200 & 64 \\
\hline
\end{tabular}




\section{EFFECT OF CONTACT TIME:}

EUCALYPTUSBARK(TimeVs \% Adsorption curve )

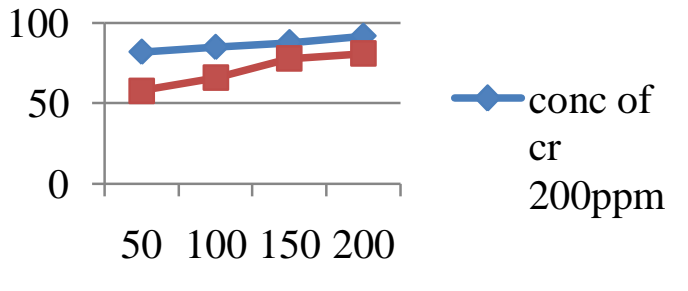

RICE HUSK (Time Vs \% Adsorption)

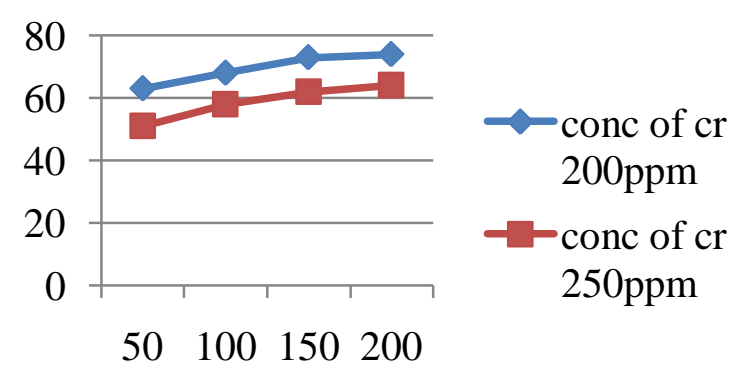

SAW DUST(Time Vs \% Adsorption curve)

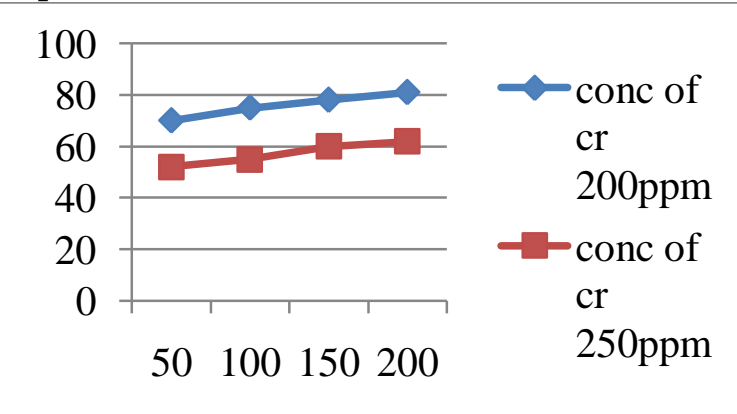

\section{Adsorption Isotherm}

Adsorption isotherms, which are the presentation of the amount of solute adsorbed per unit of adsorbent, as a function of equilibrium concentration in bulk solution at constant temperature, were studied. The equilibrium data obtained were fitted to Langmuir isotherms.

- Linear form of Langmuir equation,

$\mathrm{Ce} / \mathrm{x} / \mathrm{m}=\mathrm{k}_{1} \mathrm{Ce}+1 /\left(\mathrm{k}_{1} * \mathrm{k}_{2}\right)$

- Freundlich isotherm $\mathrm{x} / \mathrm{m}=\mathrm{kCe}^{1 / \mathrm{n}}$

langmuir adsorption (Ce Vs Ce/x/m)

(Eucalyptus bark is used as adsorbent)

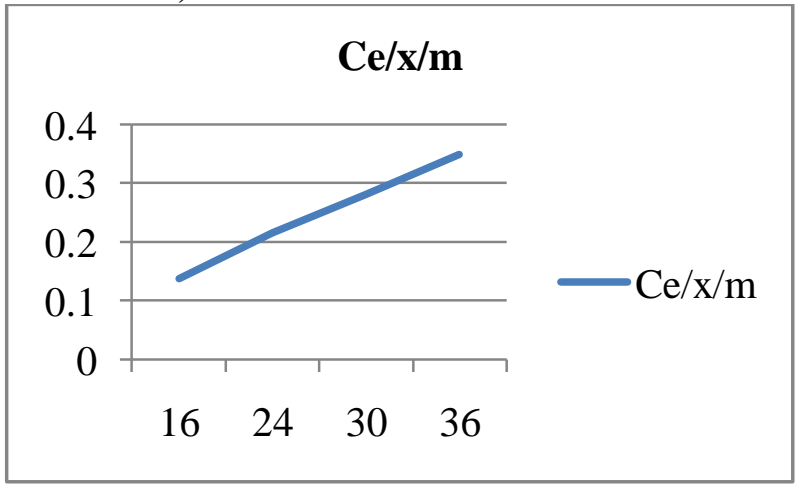

(conc-200ppm) 


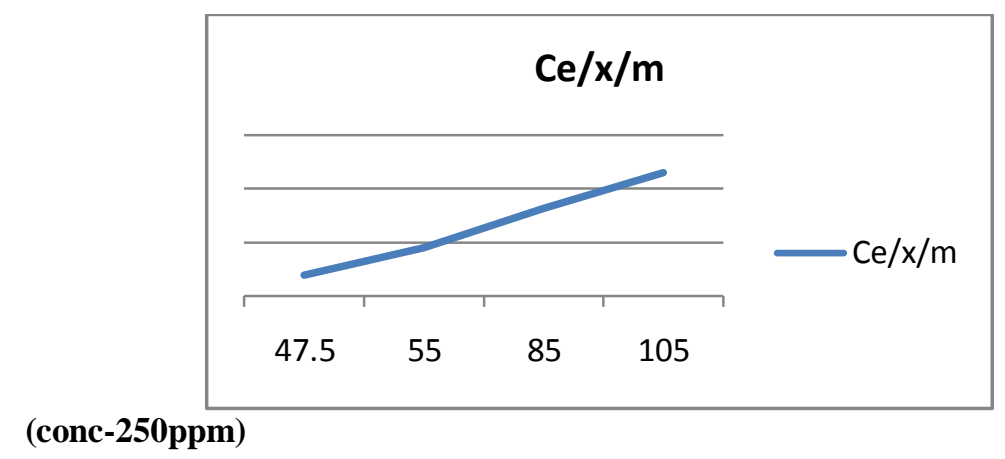

langmuir adsorption (Ce Vs Ce/x/m)

(Rice husk is used as adsorbent)

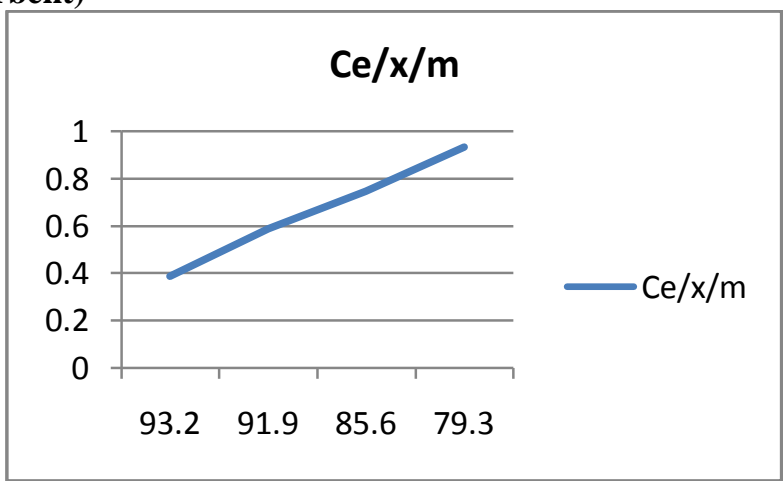

Conc $200 \mathrm{ppm}$

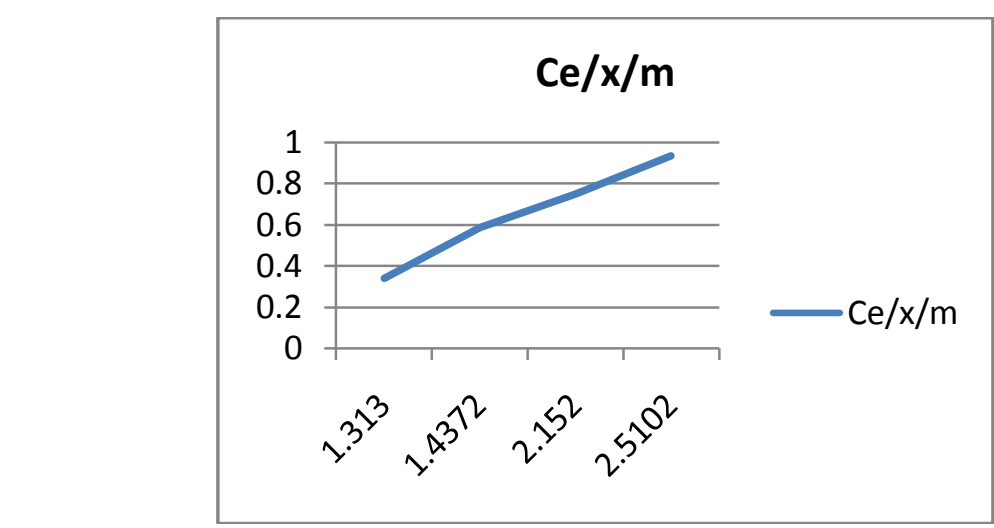

Conc $250 \mathrm{ppm}$

langmuir adsorption (Ce Vs Ce/x/m )

(sawdust is used as adsorbent)

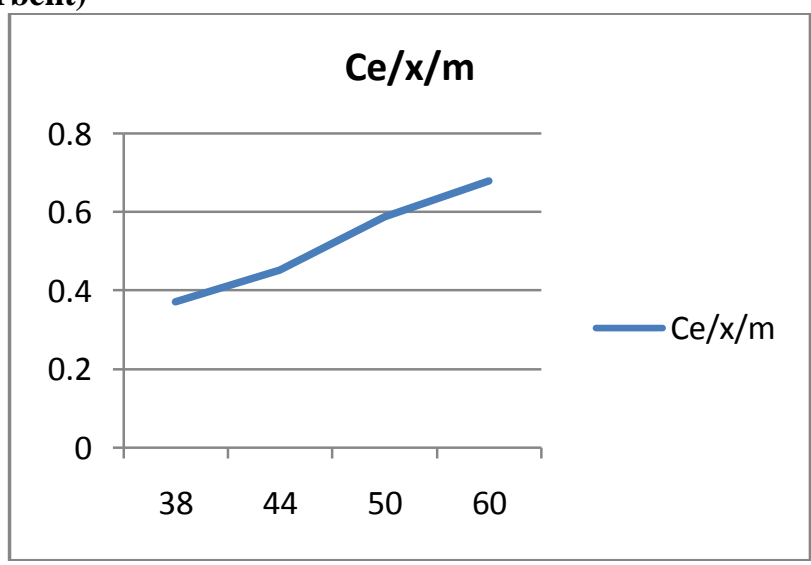

Conc 200ppm 


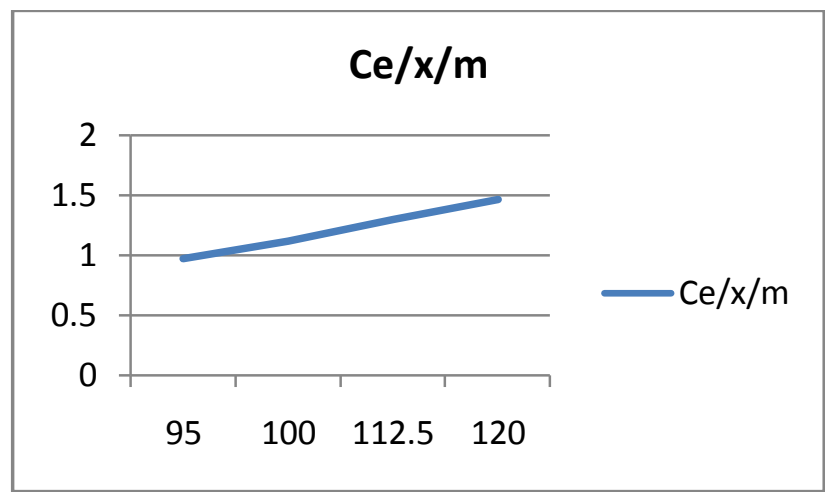

Conc 250ppm

\section{Discussions:}

The maximum (92\%) removal of chromium was achieved with EB.The percent chromium removal with other two adsorbents were significantly low as compared to EB (rice husk 26\% and sawdust 35\%)The variation in the adsorption capacity between the various adsorbents could be related to the nature and concentration of surface groups responsible for interaction with the metal ions. The selected adsorbents were cellulose based plant fibers having many hydroxyl groups that may bind the $\mathrm{Cr}(\mathrm{VI})$ ion. Formaldehyde pretreatment of eucalyptus bark led to crosslinking of compounds in the bark to form a phenol-formaldehyde copolymer that preserved high capacity of the support towards the adsorption of cations. Increasing contact time from $0.25 \mathrm{~h}$ to $3 \mathrm{~h}$ increases $\% \mathrm{Cr}$ removal. Maximum $\mathrm{Cr}$ removal was observed with in first $2 \mathrm{~h}$. Eucalyptus bark (EB) was the most effective for which the removal reached more than $87.4 \%$ for $\mathrm{Cr}(\mathrm{VI})$ at concentration of $200 \mathrm{ppm}$ and at $\mathrm{p}^{\mathrm{H}}=2$. Increase in the dose of adsorbent, initial concentration of $\mathrm{Cr}(\mathrm{VI})$ and increase in contact time upto $2 \mathrm{hr}$ are favorable for all increase the adsorption of $\mathrm{Cr}(\mathrm{VI})$. Adsorption of chromium depends on the adsorbate concentration and contact time.

\section{References}

[1] Acar, F.N., Malkoc, E., 2004. The removal of chromium(VI) from aqueous solutions by Fagus orientalis L. Bioresource Technol. 94,13-15.

[2] APHA, 1992. Standard Methods for the Examination of Water and Wastewater, 18th ed. APHA, Washington, DC.

[3] Cieslak-Golonka, M., 1995. Toxic and mutagenic effects of chromium( VI). Polyhedron 15, 3667-3689.

[4] Dahbi, S., Azzi, M., de la Guardia, M., 1999. Removal of hexavalent chromium from wastewaters by bone charcoal. Fresenius J. Anal.Chem. 363, 404-407.

[5] Dakiky, M., Khamis, M., Manassra, A., Mer_eb, M., 2002. Selective adsorption of chromium(VI) in industrial wastewater using lowcost abundantly available adsorbents. Adv. Environ. Res. 6, 533-540.

[6] Huang, C.P., Wu, M.H., 1977. The removal chromium(VI) from dilute aqueous solution by activated carbon. Water Res. 11, 673679.

[7] Kemmer, N.F., 1988. Precipitation, 10.18-10.20, Nalco Water Handbook,Publisher McGraw Hill (Chapter 10).

[8] Kowalski, Z., 1994. Treatment of chromic tannery wastes. J. Hazard.Mater. 37, 137-144.

[9] Namasivayam, C., Yamuna, R.T., 1995. Adsorption of Chromium(VI) by a low cost adsorbent: biogas residual slurry. Chemosphere 30,561-578.

[10] Orhan, Y., Buyukgangor, H., 1993. The removal of heavy metals by using agricultural wastes. Water Sci. Technol. 28, 247-255.

[11] Patterson, J.W., 1977. Waste Water Treatment. Science Publishers, New York.

[12] Randall, J.M., Hautala, E., Waiss, A.C., 1976. For. Prod. J. 26, 46.

[13] Saliba, R., Gauthier, H., Petit-Ramel,M., 2002. Adsorpt. Sci. Technol.20 (2), 119-129.

[14] Sharma, D.C., Foster, C.F., 1994. A Preliminary examination into the adsorption of hexavalent chromium using low-cost adsorbents.Bioresource Technol. 47, 257-264.

[15] Singh, T.S., Pant, K.K., 2004. Equilibrium, kinetic and thermodynamics studies for adsorption of As(III) on activated alumina. Sep.Pur. Technol. 36, 139-147.

[16] Tan, W.T., Ooi, S.T., Lee, C.K., 1993. Removal of chromium(VI) from solution by coconut husk and palm pressed fibers. Environ.Technol. 14, 277-282.

[17] Weber Jr., W.J., 1967. Sorption from solution by porous carbon. In:Faust, S.D., Hunter, J.V. (Eds.), Principles and Applications of Water Chemistry. John Wiley \& Sons, New York (Chapter 5 